\title{
Possessive Structures as Evidence for DP in West Greenlandic
}

\author{
KATHLEEN LANGR \\ University of Washington*
}

\section{$1 \quad$ Introduction}

The goal of this paper is to provide evidence for the existence of a DP projection in the West Greenlandic branch of Inuit. West Greenlandic (WG) does not have articles, which are typically the assumed occupants of the D-layer. The absence of articles has led to cases supporting NPonly structures in WG (Sadock 2003), the Inuktitut branch of Inuit (Compton 2004; Johns 2007, 2009), and articleless languages in general (Bošković 2008, 2012). I argue against these previous accounts, first by discussing the negative implications of a DP-less structure and then by introducing a possessive structure with a DP-layer that can account for the WG data. My argument proceeds as follows: in Section 2 I introduce the relevant WG data for nominals and possessives; in Section 3 I discuss the implications of a DP-less structure; in Section 4 I propose a DP structure to account for WG possessives; I conclude in Section 5.

\section{$2 \quad$ Nominals and Possessives in West Greenlandic}

\subsection{Order of Elements}

As a polysynthetic language (Fortescue 1984; Mithun 1999; Sadock 2003) WG has a fixed wordinternal morpheme order in the nominal domain. The noun root appears in the leftmost position and is followed by adjectival modifiers, number marking, and structural case ${ }^{1}$ :

(1) iluliar-sua-q...

ice.berg-big-SG.ABS

'(the) giant iceberg...'

(Sommer, Berthelsen, \& Holm 2005b:9)

(2) qajar-pa-ssui-t...

kayak-group-big-PL.ERG

'the big mob(PL) of kayak men...'

(Sommer, Berthelsen, \& Holm 2005a:12)

\footnotetext{
* Many thanks to my advisor, Barbara Citko, for her guidance on the research and theoretical development of this paper. Thanks also to others who have given me feedback for this subject and related work: Edith Aldridge, Julia Herschensohn, Karen Zagona, Allison Germain, members of the UW Syntax Roundtable, and the audience at the $40^{\text {th }}$ annual meeting of the Berkeley Linguistics Society. Any errors are my own.

${ }^{1}$ Abbreviations: SG (Singular), PL (Plural), 1 ( ( $^{\text {st }}$ Person $), 2$ ( $2^{\text {nd }}$ Person, 3 ( $3^{\text {rd }}$ Person $), F(F e m i n i n e), i F$ (Interpretable feature), uF (Uninterpretable feature), ABS (Absolutive), ERG (Ergative), INS (Instrumental), DAT (Dative), NOM (Nominative), ABL (Ablative), INE (Inessive), POSS (Possessive), ANTIP (Antipassive), PFV (Perfective), INTR (Intransitive), TR (Transitive), IND (Indicative), FUT (Future), W (Weak inflection)
} 
In addition, numerals, adjectives, and demonstratives modify nouns as separate 'words.' These exhibit concord in that they agree in number (and case when relevant) ${ }^{2}$ :

(3) Qimmi-mik taassuma-mik angituq-mik... dog-SG.INS that-SG.INS big-SG.INS 'that big $\operatorname{dog} . .$. '

(Sadock 2003:26)

(4) qimmi-t qaqurtu-t marluk taakku dog-PL white-PL two(PL) those(PL) 'those two white dogs' $\quad$ (Fortescue 1984:118)

Other modifiers, such as relative clauses and adjectival compounds show similar agreement when modifying a head noun.

\subsection{Possessive Constructions in WG}

In possessive constructions, the possessor precedes the possessum. The possessum is marked for case and agrees with its possessor in person and number. The example in (5) demonstrates this agreement: the possessum ami- 'skin' is marked with $3^{\text {rd }}$ singular agreement (matching its possessor qasigissa- 'harbor seal') and is itself marked as singular. Possessors are marked with ergative case. $^{3}$
(5) [qasigissa-p
ami-a]
panir-sima-su-q
[harbor.seal-SG.ERG skin-3SG.SG.ABS]
'The seal skin was dry.'
dry-PFV-INTR-3SG
(Sommer et al. 2005b:5)

Pronominal possessive constructions show the same type of agreement. In (6) the possessum qatanngut- 'sibling' shows possessor agreement for $3^{\text {rd }}$ person singular 'his' and is marked as plural:

(6) qatanngut-isa

sibling-3SG.PL

'his siblings'

(Sommer, Berthelsen, \& Holm 2007:6)

Pronouns are not obligatory but may appear for the purpose of emphasis.

\footnotetext{
2 The examples in (3) and (4) also show that the order of non-incorporated modifiers may vary. For an account of how these orders occur and are restricted, I refer the reader to Langr (2014).

${ }^{3}$ Example (5) and subsequent examples follow the convention shown in WG texts (e.g. Fortescue 1984), where the possessor is marked first (here: $3 \mathrm{SG}$ ) and possessed noun second (here: $\mathrm{SG}$ ).
} 


\subsection{The Possessive Agreement Paradigm}

Possessive morphemes, exemplified in (5) and (6), tend to be fused, which can mask the agreement patterns described above. However, outside of the $3^{\text {rd }}$ person singular agreement shown in (5) it is possible to distinguish person and number agreement for the possessor and possessum. Take, for example, a selection of the agreement paradigm for possessed nouns appearing in the absolutive case (like the example in (5)):

(7) Table 1: Absolutive Morphology for Possessives

\begin{tabular}{|c|c|c|}
\hline Possessor & $\begin{array}{l}\text { Singular } \\
\text { Possessum }\end{array}$ & $\begin{array}{l}\text { Plural } \\
\text { Possessum }\end{array}$ \\
\hline $1^{\mathrm{st}} \mathrm{SG}$ & -ga & -kk \\
\hline $1^{\mathrm{st}} \mathrm{PL}$ & -(r)put & -vut \\
\hline $2^{\text {nd }} P L$ & $-\underline{(\mathbf{r})} \mathrm{si}$ & -__si \\
\hline $3^{\text {rd }} \mathrm{SG}$ & $\underline{-\mathbf{a}}$ & $\underline{-i}$ \\
\hline $3^{\text {rd }} \mathrm{PL}$ & - $\underline{\mathbf{a}} \mathrm{t}$ & $-\mathbf{i} /$ at \\
\hline
\end{tabular}

(Fortescue 1984:207)

Bolded, underlined portions indicate the differences between singular and plural possessed nouns. Empty underlines indicate that no overt morphology is present.

The pattern in Table 1 can be seen in example (8). In (8b), the possessive morpheme is realized as - $m a$ ( $1 \mathrm{SG} . \mathrm{SG}$ ) rather than - $g a$ as predicted in Table 1 due to WG assimilation properties.

(8) a. issi = eye (root)

b. issima $=$ my eye (SG. possessum)

c. issík $=$ my eyes (PL. possessum)

("Greenlandic to English Dictionary" n.d.)

Given the pattern seen here, I suggest that, contrary to the agreement ordering suggested by glossing patterns in WG texts, number marking of the possessum precedes possessor agreement on possessed nouns.

\subsection{Possessive Agreement Patterns in WG: Evidence from Hungarian}

The possessive agreement pattern I suggest in Section 2.3 is not uncommon; Hungarian, for example, exhibits the same type of possessive agreement as WG and the relative order of the relevant morphemes is the same as the order I suggest for WG. In the following examples, the 
possessive marker precedes the number marking of the possessum, which in turn precedes possessor agreement marking ${ }^{4}$ :
(9)
$\begin{array}{lll}\text { a } & \text { te } & \text { kalap-ja-i-d } \\ \text { the } & \text { you.NOM } & \text { hat-POSS-PL-2SG }\end{array}$
'your hats'
(Szabolcsi: 1994:1)
(10) (a) Mari kalap-ja-i
the Mari.NOM hat-POSS-PL(-3SG)
'Mari's hats'
(Szabolcsi 1994:1)

The only difference seen between the Hungarian examples and the ones shown for WG is the presence of a possessive marker -ja immediately following the possessum. As it turns out, WG does have possessive markers such as this (POSS in the structure in (11)). However, these only appear with constructions involving alienable possession:
(11) piniartu-p
niqi-ut-aa
hunter-SG.ERG
meat-POSS-3SG.SG.ABS
'the hunter's meat'
(Fortescue 1984:216)

I will return to possessive agreement in Section 4.

In this section I have presented the basic ordering and agreement patterns for WG noun phrases and possessive constructions. Additionally, I have shown that agreement marking on possessed nouns patterns with Hungarian in that it follows the ordering: nominal root $>($ POSS $)>$ number of possessum $>$ possessor agreement. In the next section I briefly discuss the implications of assuming a WG nominal structure that does not include a DP-layer.

\section{$3 \quad$ Implications of a DP-less Structure}

\subsection{Variable Maximal Projections}

Bošković (2005, 2008, 2012, and references therein) has extensively argued for an NP-analysis of articleless languages, first in Serbo-Croatian (2005) and then crosslinguistically (2008) using a set of criteria (one of which is polysynthesis). ${ }^{5}$ In addition, Compton (2004) argues directly against a DP-analysis of the Inuktitut branch of Inuit.

Taken at face-value, an NP-analysis of WG will need to posit additional functional structure even if it does not involve a DP. For example, Compton (2004:24) proposes that

\footnotetext{
${ }^{4}$ A peripheral observation: In (10) agreement with a third singular possessor exhibits null morphology (also observed in WG, as shown above).

${ }^{5}$ I do not provide a detailed application of Bošković's criteria to WG, though see Norris (2014) for an account of why they fail to hold in Estonian (an articleless language).
} 
referentiality (a semantic feature normally inherent to D) might be handled in a little $n$ projection, à la Marantz (2000). However, he has to posit Q(uantifier) and Dem(onstrative) heads above this projection to account for the occurrence of these elements. The possible structural contrast between (12a) and (13a) is represented as (12b) and (13b), respectively:

(12) a. iluliar-sua-q... ice.berg-big-SG.ABS '(the) giant iceberg...'

(Sommer et al. 2005b:9)

b. $\quad[n$ P iluliar-sua-q]

(13)

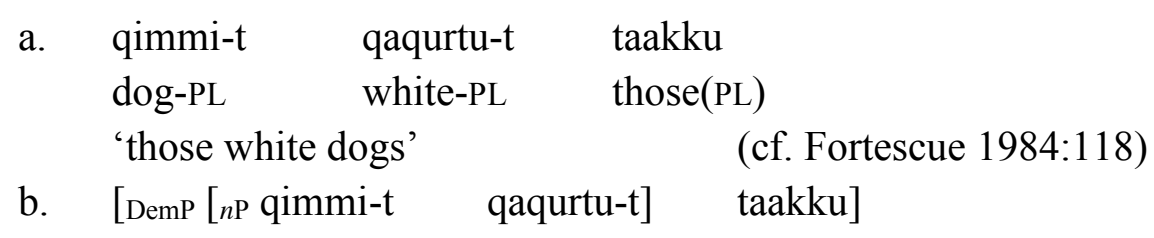

I do not oppose the existence of a DemP projection for demonstratives; in fact, I adopt Brugè's (2002) analysis of a low DemP following the strong argument that a D-head is not needed for this purpose.

Under a Bošković-style approach, modifiers of the noun (including demonstratives, adjectives, and possessives) are either adjuncts or multiple specifiers of NP. In either approach, the number of allowable NP-specifiers needs to be relatively unconstrained, but these specifiers/adjuncts need to be ordered with respect to each other. An unlimited-specifier approach has a hard time explaining these ordering restrictions.

As I will show in Section 4, adopting a What-You-See-Is-What-You-Get approach to DPs need not be adopted at the expense crosslinguistic uniformity. In the following section, I point out an issue with the NP-analysis of WG noun phrases.

\subsection{Morphosyntax of Possessive Constructions}

Compton (2004) does not suggest an analysis of possessive constructions in Inuktitut, leaving a hole in his argument for a no-D analysis of Inuit. On the other hand, Bošković-style approaches support an analysis of possessors in Serbo-Croatian whereby possessors and demonstratives are analyzed as adjectival elements, based on factors such as possessors exhibiting concord with the head noun/possessum:

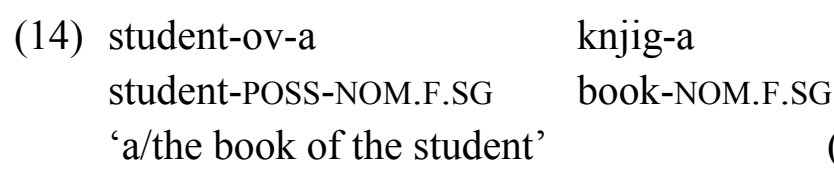

(Zlatić 2000:180) 
$\begin{array}{ll}\text { mam-in-og } & \text { brata-a } \\ \text { mom-POSS-GEN.M.SG } & \text { brother-GEN.M.SG }\end{array}$

'of the mother's brother'
(Zlatić 2000:179)

The examples in (14) and (15) differentiate Serbo-Croatian possessives from WG in two ways: (i) as shown in (5) above, it is not the case that possessors show concord in $\mathrm{WG}^{6}$ and (ii) though a POSS marker is present, it occurs on the possessor rather than the possessum as in WG (example (11)). An analysis of WG possessors as adjectival modifiers cannot be upheld in the absence of the indicative concord marking and the difference in POSS marking.

In the next section I present an account of possessives that can account for the data as given in the preceding sections. I show that without a DP projection, possessor marking and the ordering of the possessive morphemes as shown in Section 2.3 remains problematic.

\section{A DP Analysis of WG Possessives}

\subsection{Basic WG DPs}

I propose that the structure of a basic noun phrase in WG has three projections: NP, NumP (independently motivated by Ritter 1991 and others), and DP. Each head is associated with a distinct set of interpretable features; interpretable (iP) ${ }^{7}$ and uninterpretable number (uNum) on $\mathrm{N}$, interpretable number (iNum) and uninterpretable person (uP) on Num, and uninterpretable definiteness (uDef $)^{8}$, person, and number on D.

For a DP such as (16), the derivation proceeds as in (17). In (17a) the $\mathrm{N}$ and Num heads merge with their given (un)interpretable features; the interpretable instances of features value the uninterpretable ones via feature-sharing (Frampton and Guttman 2006; Pesetsky and Torrego $2007)^{9}$. At the merge of $\mathrm{D}$ in $(17 \mathrm{~b})$ the number and person value their uninterpretable instances once more. In (17c) uDef is valued as indefinite as default:

(16)

$$
\begin{aligned}
& \text { iluliar-q... } \\
& \text { ice.berg-SG.ABS } \\
& \text { '(an) iceberg...' }
\end{aligned}
$$

(cf. Sommer et al. 2005a:5)

\footnotetext{
${ }^{6}$ See also Norris (2014) for an account of Estonian that disproves such an analysis of possessors.

${ }^{7}$ There exist arguments for person being a feature of D rather than N (Abney 1987; Carstens 2000, 2001; Danon 2011; Postal 1969); I argue that person appears in N, following Pereltsvaig's (2007) argument for Russian (an articleless language) that pronouns (inherently linked to person) merge in $\mathrm{N}$ and may raise to $\mathrm{D}$.

${ }^{8}$ I suggest definiteness is uninterpretable on D because it may be valued by DP-internal factors (e.g. demonstratives) and DP-external factors (e.g. focus/topicalization). DP-external valuation can be the result of the DP's location in larger syntactic structure (CP or $v$ P), much like Diesing's (1992) for German scrambling and Biskup (2006, 2009) for Czech scrambling.

${ }^{9}$ The structures presented here are also compatible with a Multiple Agree approach (Hiraiwa 2001) and Concord (Carstens 2000, 2001).
} 
(17)a.

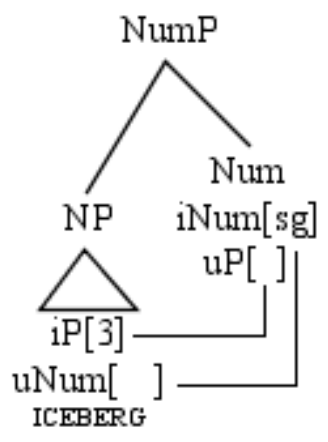

b.

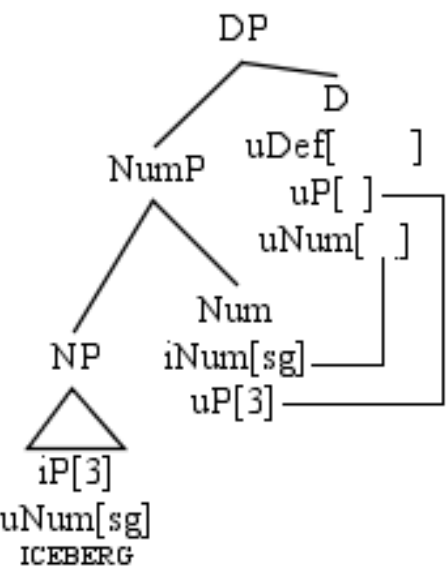

c.

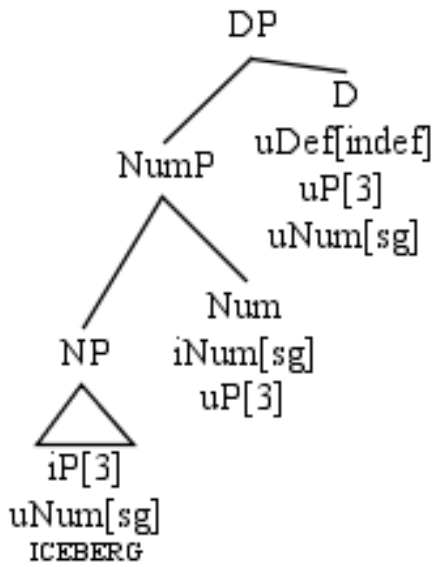

With this basic structure in place I move to possessive DPs.

\subsection{WG Possessive DP Structure - Initial Analysis}

In order to account for the possessive data, I suggest that there is a PossP projection within the possessive DP immediately below DP (Anderson 1983-84; Longobardi 1994; Ritter 1991; Siloni 1997). It is in the specifier of the PossP projection that the possessor merges and receives its possessive (ergative) case. I assume inherent assignment of ergative case in this position based on parallels between possessors and ergative subjects in WG (Aldridge 2008 and references therein; Fortescue 1995).

An initial possessive structure (to be revised) for the example in (18) is derived in (19). In (19a), we see the merge and feature-sharing of NP and NumP as shown in Section 4.1. The PossP projection is merged in (19b), its specifier being the merge site of the possessor. Finally, in (19c), the D head merges and probes for the closest person and number features available (those of the possessor DP):
Sacajawea-p
uqasiq-isa
Naya Nuki aliagi-tsagtitqipa-at
Sacajawea-SG.ERG word-3SG.PL.ERG
N.Nuki be.sad.about-IND.TR-3PL.3SG ${ }^{10}$
'Sacajawea's words made Naya Nuki feel very sad.' (Thomasma 2007:22)

\footnotetext{
${ }^{10}$ Verbal gloss has been simplified.
} 
(19) a.

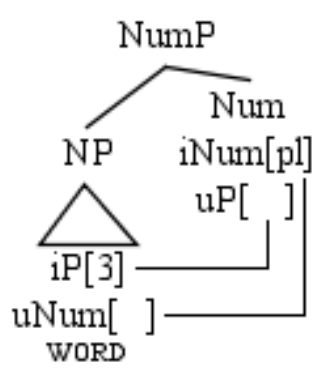

b.

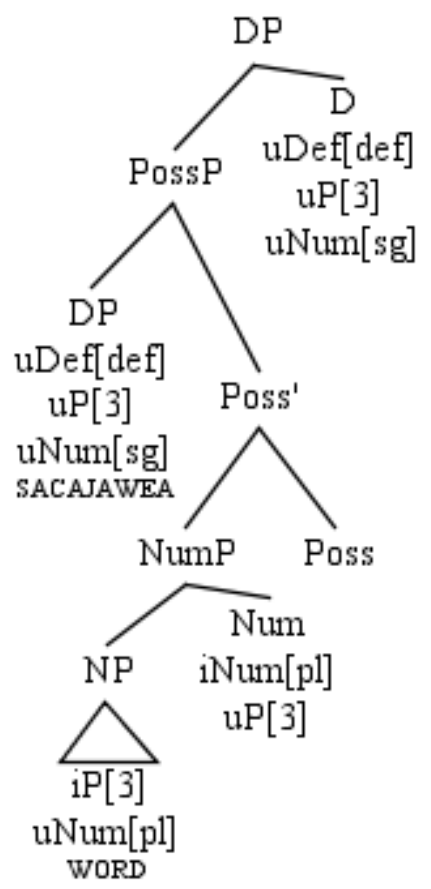

c.

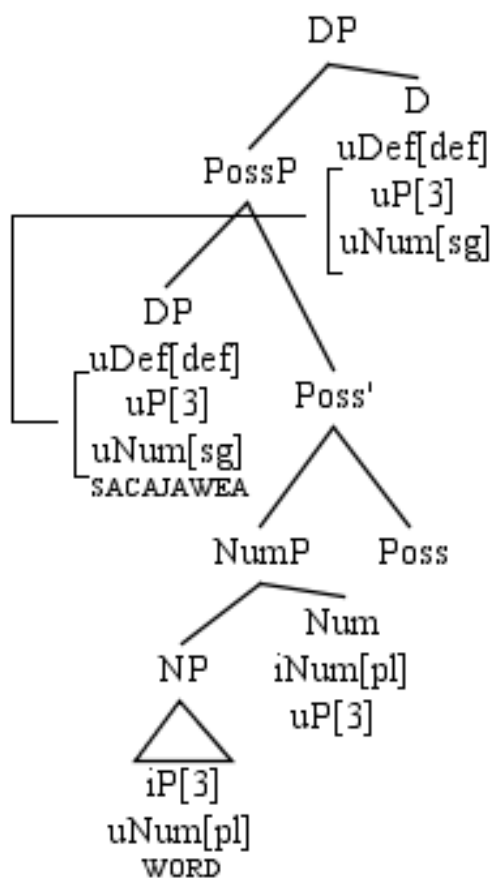

The feature-sharing of the possessor DP with D allows for the observed morphological representation of possessive agreement: we now have an explanation for why possessor features appear on the possessum. Additionally, the ordering of features that appear in the possessive morpheme can be explained: the number of the possessed noun precedes the person and number of the possessor.

What remains is an explanation of why the possessor does not trigger verbal agreement; for example, what causes the features of the possessed nominal rather than the possessor in (18) to agree with the verbal complex (underlined in (18))? In the next section I discuss existing explanations of agreement and propose an account for WG.

\subsection{Accounting for Verbal Agreement}

\subsubsection{Previous Approaches}

Historically, there appear to be two types possibilities explaining verbal agreement with a possessed noun in a language showing WG-style agreement: head movement and/or a DPinternal agreement projection. The former has been assumed for WG (Bittner and Hale 1996), while the latter has been suggested for Hungarian (Den Dikken 1999).

Bittner and Hale (1996) propose an account of WG whereby possessors and possessed nouns are part of a nominal small clause; the possessor is the subject and the possessum is the head of the small clause. Spec-head agreement takes place, allowing both the features of the possessor and the possessed noun to appear on the head noun. The head moves out of the small clause and incorporates into D: 
(20)

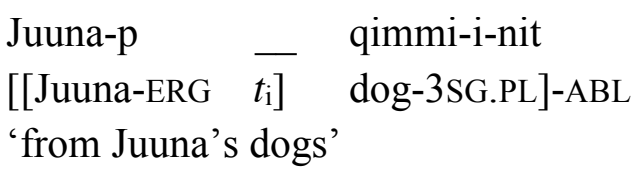

(21)

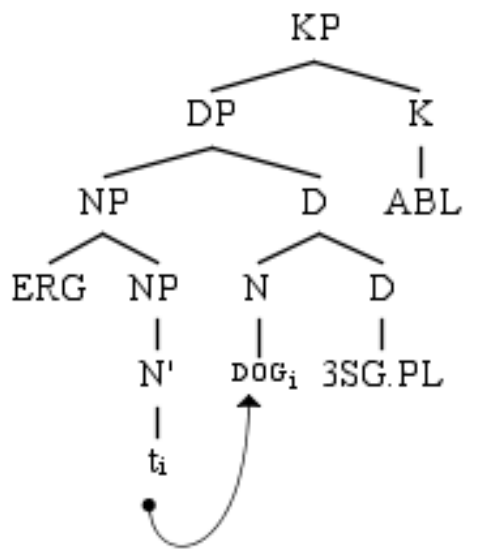

Unfortunately the possessor-possessum features are bundled into one indistinct group on D, obscuring the features specific to the head noun (which is required for verbal agreement).

For a few reasons, Bittner and Hale's account is not ideal. First, the assignment of ergative case is dependent upon a syntactic relation rather than being inherent to a head, indicating that under this approach ergative is a structural rather than an inherent case (contra the account presented here $)^{11}$. Second, though Spec-head agreement can account for the morphology, the mechanism by which the bundled features on $\mathrm{D}$ can produce correct case assignment and verbal agreement is unclear.

Den Dikken (1999) also suggests a small-clause approach to possessives but for Hungarian rather than WG. For Den Dikken, the possessed noun is the head of the small clause (as in Bittner and Hale) but the possessor originates inside the PP complement to the head:

$$
\text { [SC POSSESSUM [pP P } \mathrm{d}_{\mathrm{dat}} \text { POSSESSOR]] }
$$

(Den Dikken 1999:153)

In order to derive the Hungarian order of possessor preceding possessed noun, the possessor undergoes Predicate Inversion:

(23) a. [Dp D [sc POSSESSUM [pp $P_{\text {dat }}$ POSSESSOR]]]

b. [dp D [fp [pr Pø POSSESSOR $]_{i}$ F [sc POSSESSUM $\left.\left.\left.t_{i}\right]\right]\right]$

(cf. Den Dikken 1999:154)

Agreement of the possessor with the possessum proceeds by the Spec-head agreement of a resumptive pronoun in SpecFP with the possessum. Possessum agreement with the verb obtains via $\mathrm{D}$.

\footnotetext{
11 There are, of course, arguments that ergative is in fact a structural case, eg. Coon and Salanova (2009).
} 
My proposed construction has an observable parallel to Den Dikken's construction. First, his FP/AgrP is in the same location as my proposed PossP, and the possessor (PP for Den Dikken) is located in its specifier, like my ergative possessor. The primary differences lie in (i) the fact that my possessor does not originate low in the structure as the predicate inside the small clause and (ii) the fact that I do not posit Spec-head agreement. ${ }^{12}$

In the next section I make use of observations from both Bittner and Hale (1996) and Den Dikken (1999) to suggest a mechanism by which possessives may agree with the verb while maintaining the integrity of the structure proposed in Section 4.2.

\subsubsection{Applying Previous Accounts}

Following the insights of Bittner and Hale (1996), here I test the possibility of using headmovement to explain WG possessive constructions.

Given the structure in (19c) above, we can make use of head movement to derive the correct ordering of the features on D. First, the head noun moves from N to Num (24a); the complex head then moves from Num to Poss (24b) and then the whole complex from Poss to D $(24 \mathrm{c}){ }^{13}$

a.

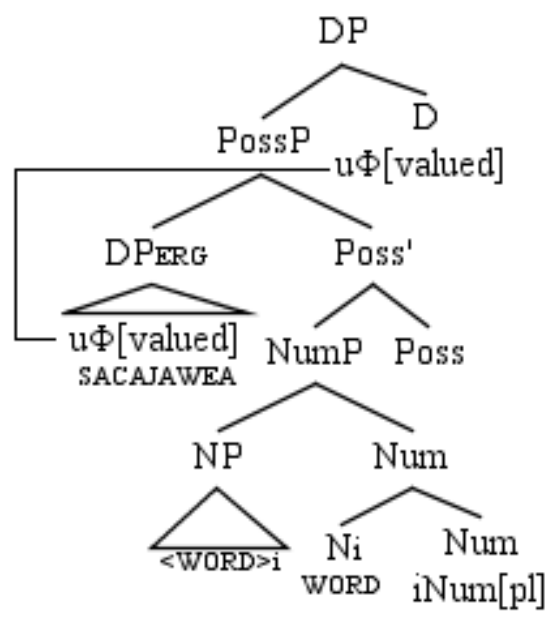

b.

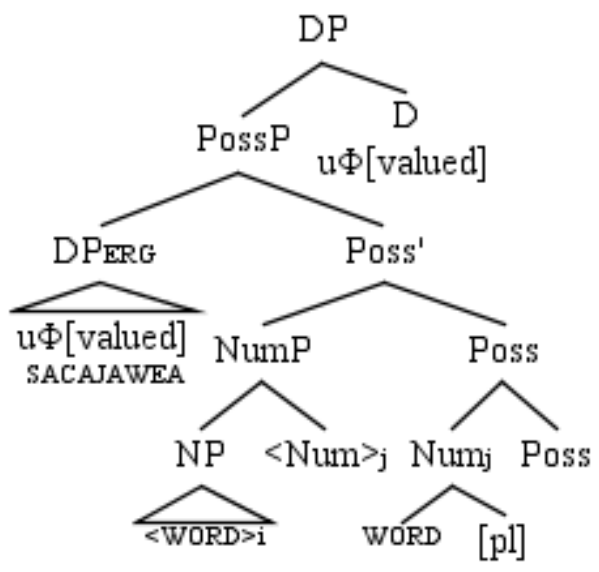

${ }^{12}$ Den Dikken must also make use of a resumptive pronoun strategy to account for a split between Nominative/Dative possessor number agreement. Since WG does not show such a split, I do not require such an account.

${ }^{13}$ I use $u \Phi[$ valued] as a shorthand reference to the features shared between the possessor DP and D-head. 
c.

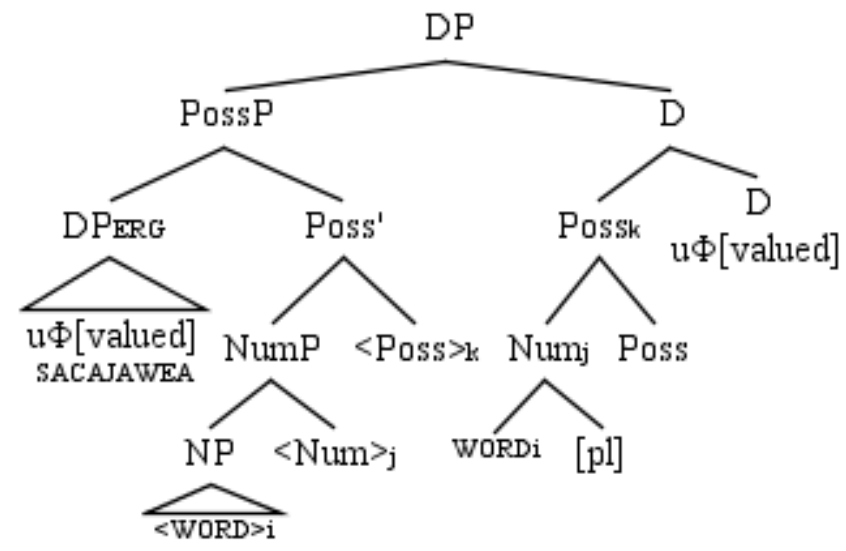

Alas, however, we still run into issues when it comes to agreement because our D head now has two sets of $\Phi$-features; additionally, the possessor features are where we would expect the agreeing noun to be located.

The structure in (24) also reveals an issue of ordering at the level of the Poss head. Recall example (11), repeated here, which shows that possessive markers do exist in WG:

(25) pin

$\begin{array}{ll}\text { piniartu-p } & \text { niqi-ut-aa } \\ \text { hunter-SG.ERG } & \text { meat-POSS-3SG.SG.ABS }\end{array}$

'the hunter's meat'

(Fortescue 1984:216)

Logically, a POSS marker is expected to be part of the Poss head. But when we examine the order of elements on Poss in (24b) the derived order is possessum number $>($ POSS $)>$ possessor agreement.

While this observation is problematic for a head-movement approach, it lends benefit to a $\mathrm{DP}$-argument in general. If we were to take a DP-less approach to possessives and PossP were the maximal projection, with possessor agreement being the result of Spec-head agreement, it would not be possible to derive the correct order at all: the possessum features would always precede the Poss marker.

In the next section, I abstract away from a head-movement/spec-head agreement approach and suggest that the problem does not reside with the structure itself but rather the timing and mechanisms of agreement.

\subsubsection{Two Types of Agreement}

One feature that Bittner and Hale (1996) and Den Dikken (1999) share is that each approach to possessives involves two types of agreement; this similarity should not go unnoticed. For Bittner and Hale, we have Spec-head agreement followed by case assignment; for Den Dikken we have (presumably) some sort of concord operation (allowing the matrix nominal's features to be part of D or Agr) followed by Spec-head agreement. In either case, each mechanism is independently 
motivated. Comparatively, in what I have proposed so far, we only have one mechanism: feature-sharing. The data and previous accounts lead us to believe that we are one mechanism short.

Norris (2012) observes that possessor agreement and concord (here: feature-sharing) appear to be two distinct phenomena. Finnish, a language which, like Hungarian and WG, marks possessors as genitive (here: ergative) and has possessum agreement with the possessor, exhibits concord throughout DPs but does not allow possessor agreement to extend to the remainder of the DP as in (27):

iso-ssa talo-ssa-ni
big-INE house-INE-POSs.1sG
'in my big house'
*iso-ssa-ni talo-ssa-ni

*iso-ssa-ni talo-ssa-ni

(Norris 2012:212)

WG exhibits this same phenomenon:

$\begin{array}{ll}\text { illu-ga } & \text { mikisu-q } \\ \text { house-1sG.SG } & \text { little-SG } \\ \text { 'my little house' } & \end{array}$

(Fortescue 1984:109)

In both examples, only the possessum is marked for agreement with the possessor (even though the modifying adjective agrees with the possessum in $\Phi$-features).

According to Norris' analysis of concord, the highest head of a DP is KP (as in Bittner and Hale's approach as mentioned above), which probes for gender and number features in an Agree-like manner and receives case by a standard case-assignment mechanism. The gender, number, and case features present on $\mathrm{K}$ are copied to Agr nodes associated with the heads that show agreement, such as the adjectival head in (26). Thus concord is distinct from argumentpredicate agreement.

The proposal I present in the following paragraphs is similar to Norris' in that it recognizes the distinction between possessor agreement and concord. I depart from Norris' analysis in the particular mechanism responsible for feature-distribution. Instead of positing a collective head $\mathrm{K}$ that redistributes features, I suggest feature-sharing simply precedes possessor agreement.

Given that the possessum features are shared throughout the DP prior to agreement with the possessor, we anticipate that the mechanism causing possessor DP agreement with the possessum occurs after feature-sharing operations. What this means for the structures I have proposed is that the features on D in (19c) should be shared with the features of the matrix nominal/possessum; the fact that the separate features of $D$ do not agree with a $\Phi$-complete, case-assigned possessor is intuitively anticipated. Then, a separate mechanism causes $\mathrm{D}$ to probe for the possessor features in SpecPossP. 
The structure in (29) is a revision of the one in (19). (29a) shows the agreement of the possessum features with the features of $\mathrm{D}$, while (29b) shows the probing mechanism (equivalent to standard Agree) selecting the features of the DP in PossP (indicated by double-lines):

(29) a.

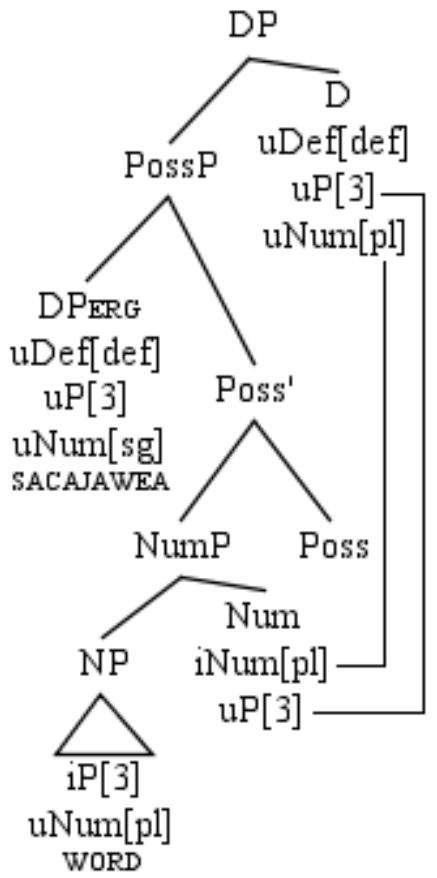

b.

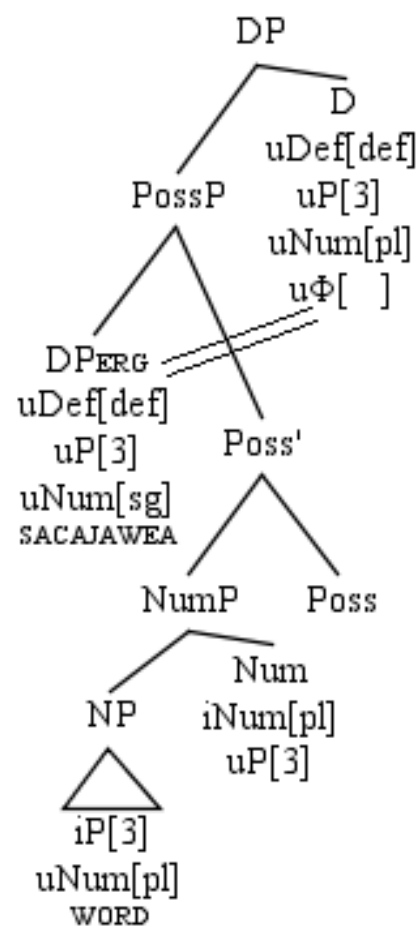

This post feature-sharing probing mechanism explains the morphosyntactic patterns discussed in Section 2.3 as well as the absence of possessor agreement on modifiers. What remains is D's motivation to probe for possessor features.

The answer to this question may lie in the verbal domain. An approach to possessor agreement that is separate from concord/feature-sharing helps to capture the well-known parallel between possessors and subjects. Given this parallelism, possessive DPs can be considered 'transitive' in a sense, requiring D to probe for two sets of features. Devising such a mechanism for D would require careful comparison of DP and verbal agreement phenomena and is beyond the scope of this paper. Given the argument so far, however, such an agreement mechanism is not an unreasonable assumption.

Before concluding, I must address one final question: why does the possessor appear in the SpecPossP rather than SpecDP? Though there does not appear to be a pressing reason to have SpecDP available (e.g. for purposes of extraction - it does not seem to be the case that DPinternal elements can precede the possessor), I suggest that leaving this specifier available might explain the allowance of, for example, 'appositional' modifiers of the noun phrase. In the example in (30), the noun qisuk 'wood' could reside in SpecDP, modifying the entire possessive construction: 
(30)

$\begin{array}{lll}\text { qisuk } & \text { savi-up } & \text { ipu-ssa-a } \\ \text { wood } & \text { knife-ERG } & \text { shaft-FUT-3SG.SG }\end{array}$

'(a piece of) wood for the shaft of a knife' (Fortescue 1984:115)

Qisuk 'wood' is unmarked (or arguably marked with default $3^{\text {rd }}$ singular absolutive, but nothing leads Fortescue to believe this is the case) but still clearly related to the possessive construction.

In this section I have presented an account of WG possessives that allows the observed possessor agreement to appear on the possessum while not inhibiting possessum agreement with the verbal complex. Though the precise mechanism of the former type of agreement is not immediately apparent, it does appear to be the case that two distinct mechanisms exist - even if only to delay the agreement of the possessor with D.

\section{Conclusion}

In the preceding sections I have argued for an account of the West Greenlandic possessive noun phrase that supports the existence of a DP projection in the language. I first demonstrated how a DP account of WG can explain the appearance of possessor agreement on possessive morphemes (attached to the possessum). Then I discussed how previous accounts of possessor agreement are not quite compatible with the current theoretical assumptions. Finally, I made use of the observation that two types of agreement are necessary to account for possessive agreement in the nominal domain. By separating feature-sharing and possessor agreement, we are able to account for possessive DP agreement with the verbal domain.

Possessive agreement is just one argument for the existence of DP in West Greenlandic; however, as I have shown, the agreement patterns shown in West Greenlandic possessives are difficult to explain with an NP-only structure.

\section{$6 \quad$ References}

Abney, Steven. 1987. The English Noun Phrase in its Sentential Aspect. PhD Dissertation, Massachusetts Institute of Technology.

ALDRIDGE, EDITH. 2008. Generative Approaches to Ergativity. Language and Linguistics Compass 2(5):966-995.

Anderson, Mona. 1983-84. Prenominal Genitive NPs. The Linguistic Review 3:1-24.

BISKUP, PETR. 2006. Scrambling in Czech: Syntax, semantics, and information structure. Ms., University of Leipzig.

BisKUP, PETR. 2009. Phase Model and Adverbials. PhD Dissertation, University of Leipzig. BitTner, MARIA and Ken HALE. 1996. The Structural Determination of Case and Agreement. Linguistic Inquiry 27:1-68.

BoŠKOVIĆ, ŽELJKO. 2005. On the locality of Left Branch Extraction and the structure of NP. Studia Linguistica 59(1):1-45. 
BoŠKOVIĆ, ŽELJKO. 2008. What will you have, DP or NP? Proceedings of 37th Conference of the North East Linguistic Society, Amherst.

BoŠKOVIĆ, ŽELJKO. 2012. On NPs and Clauses. In Günther Grewendorf \& Thomas Ede Zimmerman, eds., Discourse and grammar: From sentence types to lexical categories, pp. 179-242. Boston: De Gruyter.

BRUGÈ, LAURA. 2002. The positions of demonstratives in the extended nominal projection. In Guglielmo Cinque, ed., Functional Structure in DP and IP. The Cartography of Syntactic Structures, Volume 1, pp. 15-53. New York: Oxford University Press.

CARSTENS, ViCKI. 2000. Concord in Minimalist Theory. Linguistic Inquiry 31(2):319-355.

CARSTEns, ViCKI. 2001. Multiple Agreement and Case-Deletion. Syntax 4(3):147-163.

COMPTON, RICHARD. 2004. On quantifiers and bare nouns in Inuktitut. Toronto Working Papers in Linguistics 23(1):1-45.

CoOn, JessiCA, and ANDrÉs SALANOVA. 2009. Nominalization and Predicate-Fronting: Two Sources of Ergativity. University of Pennsylvania Working Papers in Linguistics 15(1):45-54.

DANON, GABI. 2011. Agreement and DP-internal feature distribution. Syntax 14(4):297-317.

Den DikKen, MARCEL. 1999. On the Structural Representation of Case and Agreement: The Case of (Anti-)Agreement in Hungarian Possessed Nominal Phrases. In István Kenesei, ed., Crossing Boundaries: Advances in the Theory of Central and Eastern European Languages, pp. 137-178. Amsterdam/Philadelphia: John Benjamins.

Diesing, MOlly. 1992. Indefinites. Cambridge: MIT Press.

Fortescue, Michael. 1984. West Greenlandic. Sydney: Croom Helm.

FORTESCUE, MiCHAEL. 1995. The historical source and typological position of ergativity in Eskimo languages. Études/Inuit/Studies 19(2):61-75.

FrAmpton, John, and SAM GUTMANN. 2006. How sentences grow in the mind: Agreement and selection in an efficient minimalist syntax. In Cedric Boeckx, ed., Agreement Systems, pp. 121-157. Amsterdam: John Benjamins.

Greenlandic to English Dictionary. N.D. Retrieved 10 May 2013 from http://www.polarhusky.com/media/cms/investigate/StudyResources/EnglishKalaallisutDi ctionary.pdf.

HiRAIWA, KEN. 2001. Multiple Agree and the Defective Intervention Constraint in Japanese. MIT Working Papers in Linguistics 40:67-80.

Johns, AlanA. 2007. Restricting noun incorporation: root movement. Natural Language and Linguistic Theory 25:535-576.

JOHNS, ALANA. 2009. Additional facts about noun incorporation (In Inuktitut). Lingua 119:185198.

LANGR, KATHLEEN. 2014. Evidence for a DP Projection in Inuit. Ms. University of Washington.

LONGOBARDI, GIUSEPPE. 1994. Reference and proper names: A theory of N-movement and syntax in logical form. Linguistic Inquiry 25(4):609-665.

MARANTZ, ALEC. 2000. Reconstructing the lexical domain with a single generative engine. Ms. Cambridge: MIT. 
Mithun, MARIANNE. 1999. The Languages of North America. United Kingdom: Cambridge University Press.

NORRIS, MARK. 2012. Towards an Analysis of Concord (in Icelandic). In Jaehoon Choi, E. Alan Hogue, Jeffrey Punske, Deniz Tat, Jessamyn Schertz, and Alex Trueman, eds., Proceedings of the $29^{\text {th }}$ West Coast Conference on Formal Linguistics, pp. 205-213. Sommerville, MA: Cascadilla Proceedings Project.

NORRIS, MARK. 2014. Evidence for DP in Estonian (Handout). Paper presented at LSA 88, January 2-5.

Pereltsvaig, Asya. 2007. The Universality of DP: A view from Russian. Studia Linguistica 61(1):51-94.

PESETSKy, DAVID, \& ESTHER TORREGO. 2007. The syntax of valuation and the interpretability of features. In Simin Karimi, Vida Samiian, and Wendy K. Wilkins, eds., Phrasal and clausal architecture: Syntactic derivation and interpretation, pp. 262-294. Amsterdam: John Benjamins.

Postal, Paul. 1969. On so-called "pronouns" in English. In David Reibel \& Sanford Schane, eds., Modern Studies in English: Readings in transformational grammar, pp. 201-244. Englewood Cliffs, NJ: Prentice Hall.

RITTER, ElizABETH. 1991. Two functional categories in noun phrases: Evidence from Modern Hebrew. In Susan Rothstein and Stephen Anderson, eds., Syntax and Semantics 25: Perspectives on phrase structure: Heads and Licensing, pp. 37-62. San Diego: Academic Press.

SADOCK, JERROLD. 2003. A Grammar of Kalaallisut (West Greenlandic Inuttut). Muenchen: Lincom Europa.

SILONI, TAL. 1997. Noun phrases and nominalizations: The syntax of DPs. Boston: Kluwer.

SOMmer, DAVID, Chr Berthelsen, and ERLing Holm, eds. 2005a. Aataarsuup irnikasia [Aataarsuaq's kid son] (M. Bittner, Trans.) In Kalaallisut Ilinniutit, pp. 27-32. Ministeriet for Grønland. (Original work published in 1972).

Sommer, DAvid, Chr Berthelsen, and Erling Holm, eds. 2005b. Piniartup uqluttuaa [A hunter's story] (M. Bittner, Trans.). In Kalaallisut Ilinniutit, pp. 62-64. Ministeriet for Grønland. (Original work published in 1972).

Sommer, David, Chr Berthelsen, and Erling Holm, eds. 2007. Paakujuk [Sooty] (M. Bittner, Trans.). In Kalaallisut Ilinniutit 2, pp. 11-21. Ministeriet for Grønland. (Original work published in 1976).

SzaBolCSI, ANA. 1994. The Noun Phrase. PhD Dissertation, University of California, Los Angeles.

ThOMASMA, KenNETH. 2007. Naya Nuki: Niviarsiaraq qimaasuq [Naya Nuki: Shoshoni Girl Who Ran] (M. Bittner, Trans.). Jackson, WY: Grandview Publishing Company. (Original work published in 1983).

Zlatić, LARISA. 2000. The Morpho-Syntax of Slavic Possessives. In Arika Okrent and John Boyle, eds., The Proceedings from the Panels of the Chicago Linguistic Society's ThirtySixth Meeting 36(2):179-190. Chicago: Chicago Linguistic Society. 